\title{
К БИОГРАФИИ ГОРНОГО ИНЖЕНЕРА Э.А. КУПФФЕРА: МАЛОИЗВЕСТНЫЕ СТРАНИЦЫ
}

\section{Дюжилов С.А.}

Центр гуманитарных проблем Барени региона КНЦ РАН, Anaтumbl,dyuz_arcticsu@mail.ru

Удивительны бывают судьбы не только людей, но и частных коллекций и собраний. Еще в юности у Эдуарда Августовича Купффера пробудился неподдельный интерес к истории нашей планеты, «записанной загадочным языком камня» (И.В. Бельков). Позднее он напишет: «Будучи студентом Фрайбергской Горной академии в Германии, я особенно интересовался минералогией и начал собирать коллекцию минералов, толчком к чему послужила небольшая минералогическая коллекция, перешедшая мне от моего покойного деда, также в свое время бывшего студентом Фрайбергской академии и учеником знаменитого тогда профессора Вернера.

Посетив в течение ряда лет моего пребывания за границей большое количество рудников и делая экскурсии в местностях известных своими месторождениями полезных ископаемых, я постепенно собрал огромный материал, который лишь частью вошел в мою коллекцию, главным же образом служил мне обменным материалом с другими коллекционерами и минералогическими кабинетами, кроме того, очень большое количество образцов было мною через моего покойного отца пожертвовано в минералогический музей Московского Университета и Московского Сельскохозяйственного института, где в это время работал мой отец.

Ко времени окончания Академии мне удалось таким образом собрать чрезвычайно ценную и полную коллекцию минералов, к которой присоединилось небольшое количество метеоритов» [1].

В этом собрании были представлены минералогические образцы из самых разных регионов нашей планеты. И все же особый колорит, неповторимость и масштабность коллекции Э.А. Купффера придавал разнообразный каменный материал из старинных рудников Германии. В дальнейшем ее состав пополнился русскими образцами из месторождений Урала, Сибири, Алтая.

С приходом большевиков к власти минералогическая коллекция Э.А. Купффера была конфискована Петроградской Губ.ЧК и на основании прошения старшего ученого хранителя Н.П. Покровского пополнила Главное минералогическое собрание Горного музея [2], причем с течением времени в официальной документации стала подчеркиваться ее принадлежность к коллекции уже другого Купффера, не Эдуарда Августовича, а его отца Августа Эрнестовича. Впрочем, это не удивительно, если учесть, что с именем последнего, вписанным в анналы истории данного Горного музея, связана систематизация коллекций отдела минералогии и составление по новой минералогической системе каталога, не утратившего своего значения до сих пор. Понадобилось ни одно десятилетие, чтобы наконец-то восстановить настоящее авторство рассматриваемой коллекции.

В год столетия архивной службы России наше внимание привлекла публикация Е.С. Свириной и Н.В. Боровковой «Минералогическая коллекция Э.А. Купффера, сохраненная в Горном музее. Разнообразие ее минерального состава и особенности комплектования». Ее авторы, опираясь на выявленные ими и не публиковавшиеся ранее документы из фондов Горного музея СанктПетербургского государственного горного университета [1-4 и др.], опровергают бытовавшее ранее суждение о выше названной коллекции как подборке минералов, сформированной Августом Эрнестовичем Купффером из дуплетов Главного собрания музея.

В качестве весомых аргументов, приведенных на сей счет в статье Е.С. Свириной и Н.В. Боровковой, можно выделить следующие:

1. Среди входящих документов архива Горного музея сохранилось заявление, датированное 20.08.1920 г., от горного инженера Эдуарда Августовича Купффера на имя директора Петроградского Горного института о передаче на хранение его коллекции минералов и метеоритов, собранной преимущественно заявителем во время учебы в Германии в стенах знаменитой Фрайбергской Горной академии. Судя, по словам Э.А. Купффера, такой шаг для него оказался вынужденным: «По некоторым обстоятельствам настоящего времени я не могу хранить эту коллекцию у себя, т.к. помещаясь в шести больших дубовых шкафах и пяти небольших витринах, она является очень громозд- 
кой, а потому позволяю себе обратиться к Вам с покорнейшей просьбой не отказать принять ее на хранение в Горный Институт, как весьма ценное научное собрание, с тем, чтобы в случае, когда я снова буду в состоянии хранить коллекцию у себя, она была мне возвращена» [1].

2. Музейными работниками была осуществлена идентификация и систематизация тех образцов из коллекции Э.А. Купффера, которые подтверждались наличием у них первичных этикеток или ссылок на авторство. В результате проведенных работ таковых оказалось 3300 образцов, представляющих 817 минеральных видов и разновидностей.

3. Сравнительный анализ минералогического собрания Горного музея и коллекции Э.А. Купффера позволил музееведам выделить в последней в качестве неоспоримых ряд отличительных особенностей (системный принцип формирования по обобщенной минералогической классификации конца XIX в., утвердившийся в Германии и скандинавских странах, наличие устаревших наименований и синонимов названий минералов, принятых в европейских минералогических классификациях XIX в., уникальность каменного материала и др.).

Резюмируя все сказанное, Е.С. Свирина и Н.В. Боровкова замечают: «Проведенные работы и анализ полученной информации позволяют однозначно закрепить авторство коллекции за Э.А. Купффером и отнести ее к наиболее ценным поступлениям начала XX века. Качество, разнообразие и представительность минералогического материала, сформированного по системному принципу и представляющего редчайшие геологические объекты, определяют статус коллекции как уникальное собрание» [7].

К сожалению, в данной публикации представлены, как признают сами авторы, далеко неполные данные из биографии Э.А. Купффера, охватывающие преимущественно первые два с половиной десятилетия его жизни. Известно, что он потомственный дворянин, родился в Москве в декабре 1879 г.; его родителями были: отец Август Эрнестович Купффер (18.04.1842-28.07.1918) и мать Каролина Юльевна (1858-1903). После окончания гимназии в 1899 г. Эдуард пошел по стопам своего деда: обучался во Фрайбергской горной академии, которую успешно закончил, защитив дипломы по специальностям - маркшейдер и горный инженер с оценками «отлично». В декабре 1903 г. ему была присвоена квалификация инженер-металлург [7]. Во время пребывания за границей Эдуард успешно совмещал учебу с работой (в 1902-1903 гг.) на заводах и рудниках Германии.

Обретя необходимый зарубежный практический опыт по своей специальности, Э.А. Купффер возвращается в Россию. Случайно или нет, но его приезд на родину хронологически совпадает со смертью его матери. Начинается новый период в жизни дипломированного специалиста-практика, связанный уже с работой на угольных копях Украины. С 1904 по 1910 гг. Э.А. Купффер управлял каменноугольными рудниками в Донецком бассейне, вел большую разведывательную работу. С 1910 по 1916 гг. Эдуард Августович состоял помощником директора-распорядителя каменноугольного синдиката «Продуголь», руководил общими организационными и техническими работами; с 1916 г. - директор-распорядитель каменноугольного общества в Донецком бассейне и консультант по промышленным вопросам при банках [6].

Как воспринял революцию 1917 г. Э.А. Купффер, сказать трудно. Но остается непреложным фактом, что он оказался в числе тех, кто решил сотрудничать с советской властью. С 1919 г. Эдуард Августович выступает в роли консультанта Николаевской железной дороги; принимает участие в Северных колонизационных экспедициях [6], связанных с обследованием и описанием территорий с целью их дальнейшего освоения и колонизации. Так судьба связала его с Русским Севером.

С созданием 4 марта 1920 г. Северной научно-промысловой экспедиции (Севэкспедиции) Э.А. Купффер становится Уполномоченным Президиума нового учреждения ВСНХ и начальником (с 1921 г.) его горно-разведывательного отряда. Об этой странице в биографии Э.А. Купффера мы можем судить по некоторым данным, почерпнутых нами из фонда 3429 (ВСНХ СССР и РСФСР) Российского государственного архива экономики (РГАЭ) и Трудов Севэкспедиции (в частности, выпуска 14, в котором помещены тезисы доклада, читанного о работе Горно-разведывательного отряда Эдуардом Августовичем в соединенном заседании Президиума. Ученого Совета и сотрудников Севэкспедиции 14-го ноября 1921 г.). 
Рассмотрим работы Горно-разведывательного отряда в первый год его существования (табл. 1).

Таблица 1. Работы горно-разведывательного отряда Севэкспедиции в 1921 г. [5].

\begin{tabular}{|l|l|l|l|}
\hline \multicolumn{1}{|c|}{ Задание } & \multicolumn{1}{|c|}{$\begin{array}{c}\text { Количество участников, } \\
\text { пройдено пути }\end{array}$} & $\begin{array}{c}\text { Обследованная } \\
\text { площадь }\end{array}$ & \multicolumn{1}{c|}{$\begin{array}{c}\text { Собранный } \\
\text { материал }\end{array}$} \\
\hline $\begin{array}{l}\text { Горно-геологические изыскания } \\
\text { северо-западного побережья } \\
\text { Кандалакшского залива }\end{array}$ & $\begin{array}{l}\text { 12 чел. } \\
\text { Отрядом преодолено: } \\
\text { по ж/д }-2700 \text { верст, } \\
\text { пешком -500 верст, } \\
\text { водой }-300 \text { миль }\end{array}$ & 300 кв. верст & $\begin{array}{l}50 \text { пуд. полевого шпата, } \\
\text { слюды, золотоносных } \\
\text { сланцев }\end{array}$ \\
\hline
\end{tabular}

Задачей отряда было обследование залежей полезных ископаемых в районе северо-западного побережья Кандалакшского залива Белого моря и оценка их с точки зрения пригодности и благонадежности для целей разработки в промышленном масштабе. На основании имевшихся на тот момент в литературе данных, к числу могущих иметь практическое значение полезных ископаемых в пределах названного района могли быть отнесены месторождения полевого шпата и слюды (они были предметом добычи еще в XVII-XVIII вв.), и золотоносные сланцы (на них было обращено внимание лишь в начале XX в.). Отсюда главное внимание участников экспедиции при работах летом 1921 г. было направлено на обследование полевошпатовых и слюдяных месторождений, а также золотоносных кристаллических сланцев. Что же касается месторождений прочих полезных ископаемых, то исследование их производилось лишь попутно, поскольку на них приходилось наталкиваться во время хода работ по основным заданиям.

Обследования начались в районе Лоухского озера и отсюда постепенно передвигались к северу вплоть до Кандалакши. Базой отряда служил вагон-теплушка, в котором находились запасы продовольствия и снаряжения и от которого делались экскурсии к побережью Кандалакшского залива и вглубь материка, длившиеся обычно от 5 до 10 дней. По израсходовании взятого с собой продовольствия, которое приходилось носить исключительно на себе, так как кроме пешеходных троп других путей сообщения в этих местах не имелось, отряд возвращался к вагону-базе, который по мере надобности передвигался к одной из следующих намеченных железнодорожных станций [8].

Оценивая произведенные Горно-разведывательным отрядом под руководством Э.А. Купффера научно-исследовательские работы, можно указать на следующие результаты:

1. Осуществлены исследования пегматитовых жил, месторождений полевого шпата, слюды и золотоносных кристаллических сланцев, имеющие как теоретическое, так и практическое значение.

2. Произведена оценка полезных ископаемых обследованного района с точки зрения их пригодности для промышленной разработки. Установлено, что месторождения полевого шпата в пределах побережья Кандалакшского залива настолько значительны по своим запасам, что не только могут покрыть потребность внутреннего рынка, но дать также значительно больший материал для экспорта заграницу, обеспечивая таким образом в полной мере постановку добычи в крупном промышленном масштабе. Потребность внутреннего рынка России легко может быть покрыта разработкой мусковитовых белых пегматитов в пределах северо-западного побережья Кандалакшского залива, но само по себе это количество недостаточно для того, чтобы служить объектом добычи в промышленном масштабе. Что касается слюды, то для Севера России в настоящее время следует всячески поощрять ее разработку исключительно мелким кустарным способом, который позволит покрыть таким путем потребности своего внутреннего рынка. Месторождение золота в кристаллических сланцах по северо-западному побережью Кандалакшского залива должно быть признано не имеющим в настоящее время экономического значения [8].

Как видно, выводы и предложения, сделанные Э.А. Купффером по итогам работы Горноразведывательного отряда в районе северо-западного побережья Кандалакшского залива Белого моря не только давали ответ на вопрос, чем же мы владеем? Но и «с достаточной точностью намечали вехи для техники и производства» в одном из отдельно взятых уголков Русского Севера.

Пребывание Э.А. Купффера в стенах Севэкспедиции хранит немало тайн и загадок. Одна из них - его отношения с ученым и профессиональным революционером Рудольфом Лазаревичем 
Самойловичем. Оба горные инженеры, выпускники знаменитой Фрайбергской Горной академии, хорошо знавшие цену редкому коллекционному материалу. И что удивительно, и того и другого не могла не волновать судьба так называемой «коллекции Купффера». И вот Р.Л. Самойлович в 1922 г. направляет в Комитет Горного музея письмо следующего содержания: «Северная НаучноПромысловая экспедиция, имеющая целью изучение и выявление путей для практического использования естественных богатств Русского Севера, нуждается при своих работах в минералогической коллекции, вследствие чего и просит передать ей на хранение коллекцию минералов горного инженера Э.А. Купффера, который со своей стороны не встречает препятствий к передаче ее Сев. экспедиции» [4]. Действительно ли на тот момент это «ударное учреждение» не могло обойтись без этого минерального собрания? Или за этой просьбой скрывалось нечто другое, нам неизвестное? Возможно, рано или поздно мы получим ответ на этот вопрос. Так же как и на другой: «Как сложилась дальнейшая судьба самого Э.А. Купффера?

\section{Литература}

1. Архив Горного музея. Входящие документы по музеуму № 2. 1920 и 1921 гг. Л. 216.

2. Архив Горного музея. Дела Музеума Горного Института. № 5, с июля 1920 по 30 декабря 1920 г. Л. 169.

3. Архив Горного музея. Входящие документы по музеуму № 2. 1920 и 1921 гг. Л. 174.

4. Архив Горного музея. Входящие документы по музеуму № 3. 1922 г. Л. 107.

5. РГАЭ. Ф. 3429. Оп. 7. Д. 1277. Л. 18.

6. РГАЭ. Ф. 3429. Оп. 7. Д. 1489. Л. 3.

7. Свирина Е.С., Боровкова Н.В. Минералогическая коллекция Э.А. Купффера, сохраненная в Горном музее. Разнообразие ее минерального состава и особенности комплектования. URL: mineraldiversity.org/ papers/smrb... копия.

8. Труды Северной научно-промысловой экспедиции. Вып. 14: Работа отрядов Севэкспедиции в 1921 г.: предварительный отчет. Петербург: Госуд. изд-во, 1922. 95 с. 